\title{
The Influence of the Store Internal Dimensions on the Customer Loyalty: A Comparative Study between Sameh Mall and Khalid Mall
}

\author{
Jamal M. M. Joudeh ${ }^{1}$ \\ ${ }^{1}$ Marketing Department, Faculty of Economics and Administrative Sciences, Applied Science Private University, \\ Jordan \\ Corresponding: Jamal M. M. Joudeh, Marketing Department, Faculty of Economics and Administrative Sciences, \\ Applied Science Private University, Jordan. E-mail: jamaljoudeh@asu.edu.jo
}

Received: November 11, 2016

Accepted: December 10, 2016

Online Published: January 16, 2017

doi:10.5539/ijms.v9n1p139

URL: http://dx.doi.org/10.5539/ijms.v9n1p139

\begin{abstract}
Customer loyalty is among the factors that increase the competitive advantage of stores and raise its market share among the other stores. Nowadays, the issue of loyalty and customer loyalty is becoming a trend among all stores even the small stores and supermarkets that are found in the local provinces (Rajic \& Dado, 2013). The current study aims at understanding the influence of the internal dimensions of the store on the customer loyalty between Sameh mall and Khalid mall. The variables which were taken into perspective were (product quality, product range, employees, physical evidence, and prices). The sample of the study contained customers who attended both stores; 350 individuals were selected to fulfill the questionnaire and 340 questionnaires were retrieved. The results of the study showed that the price was the most influential factor that influences the loyalty of the customer for the benefit of Sameh Mall.
\end{abstract}

Keywords: internal dimensions, customer loyalty, store environment

\section{Introduction}

\subsection{Statement of the Problem}

Recently, all of the markets, malls, stores and hyper markets are following procedures that give them the chance to attract more customers and gain more profit. They began taking cautions and extra attention towards the aspects that may push the customer towards going into the mall and purchase items. Attention has been taking on all levels, including the decorations, banners, marketing aspects, colors, and theme. Some stores are even taking extra care of the type of music they run inside their store and the kind of music that would attract people inside the store.

Today the main focus in the retail business has changed. Starting in the 1980s, U. S. retailers experienced uncommon turmoil with expanded rivalry. Following quite a while of quick development, add up to retail deals started to moderate in the mid-1980s. A few specialists contribute this decrease to the achievement of market demand, while others trust it is a consequence of market expansion. It was reported that in 1980 market demand developed at double the rate of offers in retail locations. Index retailers decreased yearly store deals at a rate of $10 \%$ (Moye, 2011). According to Yo and others (1998) there are some characteristics of the store that help in either attracting or pushing away customers from a certain store, some of these characteristics can be seen as the assortment of the goods, their prices, the way the goods are presented in the store, the general environment of the store and the colors and the themes that are presented in the store. Bakers and others (1994) see that encompassing and social components in the store environment give prompts that shoppers use to their quality derivations. Moreover, store environment, stock quality, and management quality were placed to be precursors of store picture as opposed to segments of store. Many researchers have examined the influence of the store internal environment on the purchasing behavior of the customers, Hussain \& Ali (2015) stated that the internal atmosphere of the store influences the customers' purchasing behavior including "cleanliness, scent, lighting, and display/layout" (Hussain \& Ali, 2015, p. 35). While Kumar (2010) stated that the atmospheric cues within the store influence the overall evaluation of a customer towards the brands that are being sold and in that sense these cues influence the overall attraction of the customers towards the store in general. On the other hand, Hussaeini \& Jayashree (2014) stated that some of the aspects in the store including the music and the overall atmosphere influence the opinion, evaluation, and attitude of the customer towards the store. 


\subsection{Importance of the Problem}

The researcher is seeking in the current research study to compare the internal dimensions of the hyper markets on the loyalty of the customer according to their experience. This idea was carried before by Aghaei and others (2013) and Simon, Gomez, McLaughlinc, \& Wittink (2009) who studied almost the same idea along with the external dimensions which may increase the level of customer loyalty including the number of competitors, patterns of consumptions, staff and employees, and working hours, not to mention the way the items are displayed. The importance of the current study is attributed to the scarcity of the studies that are related to the food stores sectors under the current competitiveness and economic fierce. This study is planning to present some suggestions for the sake of improving the internal dimensions of the stores in order to increase the loyalty of the customers, in addition to that, the current study presents some recommendations for future studies in the field of retail and food trading sector.

\subsection{Relevant Literature Review}

From little departmental stores to hypermarkets, there has been gigantic development in the retail business. Presently, every retail location tries to draw in clients by attempting to fulfill the client's needs both by making the right item accessible for its clients and by making it simple for the client to settle on the purchasing choice. One principle purpose behind the idea is that the retail business has a great deal of contenders and with a specific end goal to be fruitful; any retail location ought to ensure that they have an edge over the others.

According to Li and others (2012), customer loyalty is a main consideration for a company's prosperity. Faithful and loyal clients are known to be less price sensitive, moreover, these clients are probably going to buy most of their needs and daily products from the same place, repeat their visits to the store whenever they feel that they need something, and forward their friends to the same place that they deal with. The authors saw that relationship of customers' attributes and conduct, and clients' view of advertising procedure (item, value, put, advancement), client esteem (quality, yield) and relationship quality on client unwaveringness. Contingent upon the sort of retail location, comfort, office and hypermarket stores' dedication is impacted by a few variables, including diverse promoting techniques (value bargains, appropriation force) and relationship quality (consumer loyalty, trust, duty).

According to Rundle (2005), customer loyalty is defined as "The state or quality of being loyal, where loyalty is defined as a customer's allegiance or adherence towards an object" (Rai \& Medha, 2013, p. 140). According to Pugazhenthi (2010) there are some issues that really influence how people choose the retail store they go to or the supermarket they get their food from; some of these factors have to do with the quality of the items presented and the diversity in the prices of these goods.

Bhatnagar \& Ratchford (2004) have analyzed the customer's decision crosswise over retail designs. The authors have concentrated on rivalry for nondurable merchandise deals among markets, accommodation stores, and nourishment distribution centers. They infer that comfort stores charge a higher cost yet minimize travel time, grocery stores draw in those customers who incline toward bigger item combinations, and nourishment stockrooms are favored by the overwhelming clients, for example, buyers with bigger families (Martinell \& Balboni, 2012). Fox, Montgomery, \& Lodish (2004) ponder purchaser shopping decisions among market retailers, mass merchandisers, and medication stores, and find that customers react to varieties in item arrangements and advancements more than costs.

In a study Yoo \& Park (1998), they aimed through their study at presenting the influence of the internal dimensions and the overall looks of the store on the internal feelings of the customer and to what extent the customer are welling to revisit that place again for the sake of shopping. Through the study the authors have applied their tools of the study (questionnaire) on a sample of 294 consumers within one of the large stores in the Korean capital. The authors found out that the internal design and the way the items are presented and displayed within the store has a positive influence on the chances of the consumer visiting the place again. In addition to that, the author found out that the prices of the items within the place are not that important for the Korean consumer as long as the product is matching their needs and desires. However, the consumer recommends with the need to pay more attention to the issue of the goods and merchandize display in the stores as it was seen one of the first factors that influence the consumers' loyalty to a certain place, also the authors recommended studying the concept of making the issue of a children's playground as something crucial when opening a store as it has a lot to do with the level of freedom that the consumers have when shopping in a certain place.

From another perspective, Baker, Greweal, \& Parasuraman (1994) tried to understand in their study the influence of the internal and dimensional aspects of the store, and the psychological environment of the store on the mental image of the store among consumers. In order to find that influence, the authors chose 297 students from 
different universities, and through the application of the questionnaire on the sample of the study the authors have found out that there is a relation between the environment of the store and the way consumers saw that store. It is found that the store is somewhat depressing regarding the music that the store had on at that time of the day. This gives indication that the physical evidence plays a vivid role in the way consumers see a certain store according to the simplest actions that the store has on, even music has an influence on the mental image of the store among consumers. According to that, the author recommends that the store managers should pay attention to type of entertainment that it presents for the customers during the shopping hours.

Another study by Clottey and others (2008) noted in their study that the environment of the store is one of the most attractive factors to the idea of the customer loyalty and dedication. In addition that, the results of the statistical analysis showed that the service quality, product quality, brands and logistics are also among the most influential factors which influence to what extent customers are loyal to the store they attend which also rhymed with what Kaura, Prasad, \& Sharma (2015) came to through their results noting that "service quality dimensions, perceived price and fairness and service convenience dimensions have positive impact on customer loyalty and customer loyalty. Moreover, customer loyalty acts as mediating variable between its antecedents and customer loyalty".

From another perspective, Hussain \& Ali (2015) noted in his study the essential and unessential variables that can influence the customer behavior within grocery stores and the different choices of the customers towards choosing the best grocery store. The results of the study showed that price, the physical evidence of the store, the speed of the caching process and the spaces influence the customer loyalty. While Zameer \& Mukherjee (2010) stated in their study that among the most influential factor that may increase or decrease the loyalty of the customers towards is the location of the store, in addition to the nature of the service that is directed to the customers, also the return and refund services in the conventional stores, compared to the mega stores which depended on the variables of the range of the products, the role of the management, and the prices. Kearney and others (2012) in their study aimed at understanding the influence of the prices, cleanliness, space, music, and physical evidence on the satisfaction of the clients; the results of the study showed that these variables in the study have a positive influence on the satisfaction of the clients since it improved the environment of the store and made more suitable for shopping purposes.

On the other hand, Mittal \& Prashar (2010) showed in their study that there is no difference in choosing the grocery store due to geographical place, but what really matters is the variety of item, prices, physical environment and the connection with the store employees.

\subsection{Hypotheses of the Study}

According to the previous debate, the current study launches from a study by Thusyanthy \& Senthilnathan (2011) titled "Customer Satisfaction in Terms of Physical Evidence and Employee Interaction" which examined the influence of the store physical evidence on the customer satisfaction. The author of the current study seeks to follow the same bath in understanding the influence of the store dimensions on the customer loyalty. The main question of the current study is:

What is the influence of the internal dimensions of the stores on the customer loyalty?

From that sense, the study seeks to go through the following variables to form the internal dimension of the stores which are:

- $\quad$ Product quality

- Product range

- $\quad$ Prices

- Employees

- $\quad$ Physical evidence

According to the previously set question and variables of the study, the researcher will go through the influence of the mentioned internal dimensions on the loyalty of the customer. Based on that the hypotheses of the study will appear as the following:

The impact of the five dimensions of the in-store shopping experience on customer retention is not the same in different retailing environments.

And from that, the sub-hypotheses will be:

- There is a statistical difference between Sameh mall and Khalid mall in the product quality.

- There is a statistical difference between Sameh mall and Khalid mall in the product range. 
- $\quad$ There is a statistical difference between Sameh mall and Khalid mall in the prices.

- There is a statistical difference between Sameh mall and Khalid mall in the employees interaction.

- There is a statistical difference between Sameh mall and Khalid mall in the physical evidence.

\section{Method}

The current study depends on the quantitative approach in which a questionnaire will be used to collect the needed data from the sample of the study. The study is comparative in its approach; the sample was retrieved from two mega stores in Zaraqa which are Sameh mall and Khalid mall, both present grocery services for the local customers.

\subsection{Procedures of the Study}

For the sake of completing the current study, the author has chosen two of the major retail shopping stores in Jordan which are Sameh mall and Khalid mall. These two stores are seen to be the largest retail stores for vegetables and fruits in the country.

In order to collect the needed data, the author depended on the questionnaire as a tool to gather the needed data so as to achieve the answer to the main study question. A total of 600 questionnaires were distributed, 300 for each store, and the sample of the study was the stores' consumers. Five variables were chosen within the stores in order to achieve the needed level of comparison between the two; these variables included product quality, product range, prices, employees, and physical evidence.

\subsection{Sampling Procedures}

The population of the study are formed by the customers who attend both Sameh and Khalid mall. The sample was 350 individual who attend these stores with 150 questionnaires for each store. 340 questionnaires were retrieved for analysis.

\subsubsection{Sample Size, Power, and Precision}

The sample of the study was chosen conveniently; the author at first meant to reach a total of 500 individuals divided on both malls. Through the distribution of the study the author managed to reach only 350 individual who were welling to answer the questionnaire of the study.

\subsection{Conceptual Framework}

According to the hypothesis of the study, the author presented the following model to form the model of the study

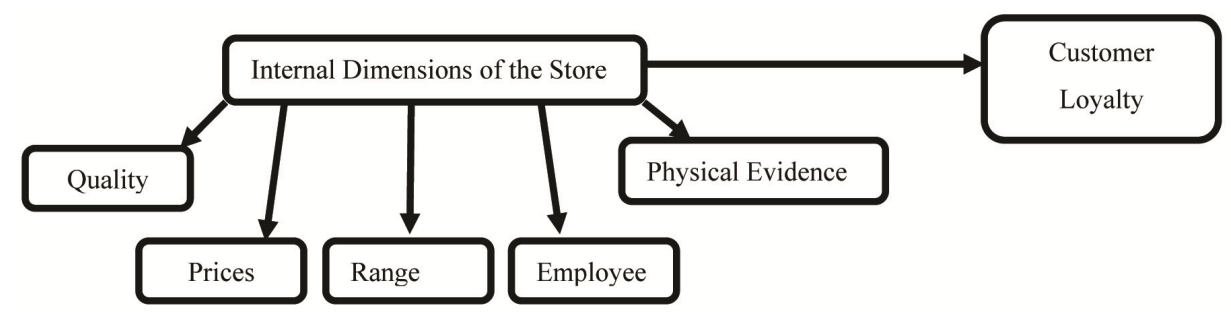

Figure 1. Model of the study

Based on the model of the study, it can be seen that the author depended on studies by Muzondo \& Mutandwa (2011) titled "The Seven Ps of Marketing and Choice of Main Grocery Store in A Hyperinflationary Economy" and by Yarimoglu (2015) titled "A Review on Dimensions of Service Quality Models".

\section{Results}

The following segment presented the analysis of the primary data which were gathered by the researcher from the sample of the study. There also appeared the reliability test, hypotheses testing, and analysis of the questionnaire paragraph.

\subsection{Demographic Variables}

Frequency and percentages were computed for the sample's characteristics. 
Table 1. Sample's distribution according to demographic information

\begin{tabular}{|c|c|c|}
\hline Category & Frequency & $\%$ \\
\hline \multicolumn{3}{|l|}{ Job } \\
\hline Housewife & 43 & 12.6 \\
\hline Public sector & 58 & 17.1 \\
\hline Private sector & 77 & 22.6 \\
\hline Private job & 88 & 25.9 \\
\hline other & 74 & 21.8 \\
\hline Total & 340 & 100.0 \\
\hline \multicolumn{3}{|l|}{ Gender } \\
\hline Male & 174 & 51.2 \\
\hline Female & 166 & 48.8 \\
\hline Total & 340 & 100.0 \\
\hline \multicolumn{3}{|l|}{ Education } \\
\hline High school & 132 & 38.8 \\
\hline Diploma & 66 & 19.4 \\
\hline Bachelor & 88 & 25.9 \\
\hline High studies & 54 & 15.9 \\
\hline Total & 340 & 100.0 \\
\hline \multicolumn{3}{|l|}{ Purchasing average } \\
\hline Less than $10 \mathrm{JD}$. & 50 & 14.7 \\
\hline 10-20JD. & 69 & 20.3 \\
\hline $21-30$ & 55 & 16.2 \\
\hline $31-40$ & 55 & 16.2 \\
\hline 41 or more & 111 & 32.6 \\
\hline Total & 340 & 100.0 \\
\hline \multicolumn{3}{|l|}{$\overline{\text { Age }}$} \\
\hline Less than 30 years & 93 & 27.4 \\
\hline $30-45$ years & 163 & 47.9 \\
\hline $46-60$ years & 75 & 22.1 \\
\hline Above 60 years & 9 & 2.6 \\
\hline Total & 340 & 100.0 \\
\hline \multicolumn{3}{|c|}{ Average of visiting numbers } \\
\hline 1 & 15 & 4.4 \\
\hline 2 & 76 & 22.4 \\
\hline 3 & 85 & 25.0 \\
\hline 4 & 45 & 13.2 \\
\hline 5 or more & 119 & 35.0 \\
\hline Total & 340 & 100.0 \\
\hline
\end{tabular}

The table 1 above indicated that $25.9 \%$ had their own job while $12.6 \%$ were housewives. On the other hand, $51.2 \%$ were males while $48.8 \%$ were females, which is somewhat strange given that females are the one who do the shopping for the family but it appeares that the percentage is really close. As for the educational level, the highest percentage of the sample had got high diploma with a percentage of $38.8 \%$.

As for the age of the sample, $47.9 \%$ of the sample was people with the age range of $30-45$ years, whereas $32.6 \%$ of the sample paid more 40 JOD per purchase. As for times of going shopping per week it can be read through the analysis that $35 \%$ of the sample noted that they go shopping more than 5 times a week which is also found to be normal for an ordinary Jordanian family.

\subsection{Analysis of the Questionnaire Paragraphs}

The following part showed that mean and standard deviation are used to describe attitudes toward following questions:

- Product range

- Prices

- Employees

- Physical evidence 
Table 2. Mean and standard deviation of the questions

\begin{tabular}{|c|c|c|c|}
\hline No. & Paragraph & Mean & Std. Deviation \\
\hline \multicolumn{4}{|c|}{ Product Quality } \\
\hline$\overline{\mathrm{Q} 1}$ & The store presents high quality goods. & 5.118 & 1.3754 \\
\hline Q2 & Goods are always fresh. & 5.026 & 1.3727 \\
\hline Q3 & There are plenty of goods and items. & 5.459 & 1.1979 \\
\hline Q4 & The quality of the goods suits me. & 5.350 & 1.2306 \\
\hline Q5 & The goods are flawless. & 5.162 & 1.5247 \\
\hline \multicolumn{4}{|c|}{ Product Range } \\
\hline Q6 & There is a vast variety of items. & 5.476 & 1.1506 \\
\hline Q7 & There is more than one brand of the same item. & 5.406 & 1.3215 \\
\hline Q8 & There is symmetry between goods. & 5.365 & 1.2560 \\
\hline Q9 & The store always adds new items. & 5.471 & 1.3488 \\
\hline Q10 & I don't usually need items from another store. & 5.035 & 1.5454 \\
\hline \multicolumn{4}{|c|}{ ( } \\
\hline Q11 & Products prices are reasonable. & 5.233 & 1.4376 \\
\hline Q12 & The store always presents promotions. & 5.538 & 1.1806 \\
\hline Q13 & The prices here are competitive. & 5.394 & 1.3361 \\
\hline Q14 & The price meets the given quality. & 5.353 & 1.2116 \\
\hline \multicolumn{4}{|c|}{ Employees } \\
\hline Q15 & Employees take good care of customers. & 5.100 & 1.4741 \\
\hline Q16 & Employees are always willing to help. & 4.956 & 1.6918 \\
\hline Q17 & The cash and register process is fast and efficient. & 4.974 & 1.6137 \\
\hline Q18 & The cash and register process is error free. & 5.371 & 1.2845 \\
\hline \multicolumn{4}{|c|}{ Physical Evidence } \\
\hline Q19 & The store's internal design is attractive. & 5.150 & 1.4486 \\
\hline Q20 & The items are distributed neatly in the store. & 5.038 & 1.4147 \\
\hline Q21 & The smells, lightening, cleanliness and ventilation are taken care of. & 5.015 & 1.4903 \\
\hline Q22 & The item presentation is attractive. & 5.129 & 1.3657 \\
\hline Q23 & It is easy here to find what you want. & 5.285 & 1.3690 \\
\hline Q24 & The spaces between the aisles and the sections are wide and comfortable. & 5.356 & 1.3567 \\
\hline Q25 & It is easy to roam around the store. & 5.332 & 1.2938 \\
\hline
\end{tabular}

Examining the above table, it can be seen that there is a positive attitude from participants towards the above questions. This appeared through the mean of the paragraphs which scored higher than 3.00 referring to the paragraph as a good indicator. As for the first variable which is the product quality, it can be seen that the most influential paragraph was the 3rd articulated: "There is plenty of goods and items" with a mean of 5.459 which refers to the idea of that people when going to stores are normally aware of the nature of the good and services that they get not only in the quality but also in the quantity they get.

Table 3. Mean and standard deviation of the variables

\begin{tabular}{lll}
\hline & Mean & Std. Deviation \\
\hline Product quality & 5.2229 & 1.05487 \\
Product Range & 5.3506 & 1.01895 \\
prices & 5.3809 & 1.08207 \\
employees & 5.1000 & 1.26310 \\
Physical evidence & 5.1866 & 1.06849 \\
Grand mean & 5.2439 & .90370 \\
\hline
\end{tabular}

Examining the above table 3, it can be seen that there is a positive attitude from participants towards the above variables. This appeared through the mean of the paragraphs which scored higher than 3.00 referring to the paragraph as a good indicator. According to the table above, the most influential variable that influences the customer loyalty and satisfaction to a certain store is the prices, given that the nature of the ordinary Jordanian families, the prices can influence the customers' attitude towards a certain merchandise destination.

\subsection{Hypotheses Testing}

The hypotheses of the study will be as follows: 
The impact of the five dimensions of the in-store shopping experience on customer retention is not the same in different retailing environments.

Table 4. Mean and standard deviation of case study samples

\begin{tabular}{lllll}
\hline Sample & $\mathrm{N}$ & Mean & Std. Deviation & $\mathrm{t}$ \\
\hline Sameh Mall & 163 & 5.2466 & 1.10331 & .053 \\
Khaled Market & 177 & 5.2414 & .67273 & \\
\hline
\end{tabular}

Independent sample t- test was used to test above hypothesis and it was found that calculated value of $(\mathrm{t})$ is not significant at $(0.05)$ which means that there is no influence of the store internal dimensions (product quality, range, prices, employees, and physical evidence) on the loyalty of customers.

\section{H1: There is a difference between Sameh Mall and Khalid mall that are attributed to product quality.}

Table 5. Analysis of the first hypothesis

\begin{tabular}{lllll}
\hline sample & $\mathrm{N}$ & Mean & Std. Deviation & $\mathrm{t}$ \\
\hline Sameh Mall & 163 & 5.2000 & 1.26296 & -.378 \\
Khaled Market & 177 & 5.2441 & .82109 & \\
\hline
\end{tabular}

Independent sample t- test was used to test above hypothesis and it was found that calculated value of $(t)$ is not significant at (0.05) which means that there is no difference between Sameh mall and Khalid mall that are attributed to product quality.

\section{H2: There are differences between Sameh Mall and Khalid Mall that are attributed to product range.}

Table 6. Analysis of the second hypothesis

\begin{tabular}{lllll}
\hline sample & $\mathrm{N}$ & Mean & Std. Deviation & $\mathrm{t}$ \\
\hline Sameh Mall & 163 & 5.4344 & 1.19662 & 1.435 \\
Khaled Market & 177 & 5.2734 & .81814 & \\
\hline
\end{tabular}

Independent sample $t$ - test was used to test above hypothesis and it was found that calculated value of $(\mathrm{t})$ is not significant at (0.05) which means that there are no difference between Sameh Mall and Khalid Mall that are attributed to product range

\section{H3: There are differences between Sameh Mall and Khalid mall that are attributed to prices.}

Table 7. Analysis of third hypothesis

\begin{tabular}{lllll}
\hline sample & $\mathrm{N}$ & Mean & Std. Deviation & $\mathrm{t}$ \\
\hline Sameh Mall & 163 & 5.5307 & 1.28883 & $2.426^{*}$ \\
Khaled Market & 177 & 5.2429 & .82848 & \\
\hline
\end{tabular}

Independent sample t- test was used to test above hypothesis and it was found that calculated value of $(t)$ is significant at $(0.05)$ which means that there are differences between Sameh mall and Khalid mall that attributed to prices and the differences came in favor of Sameh Mall.

H4: There differences between Sameh Mall and Khalid Mall that are attributed to employees.

Table 8. Analysis of fourth hypothesis

\begin{tabular}{lllll}
\hline sample & $\mathrm{N}$ & Mean & Std. Deviation & $\mathrm{t}$ \\
\hline Sameh Mall & 163 & 5.0429 & 1.52262 & -.785 \\
Khaled Market & 177 & 5.1525 & .96606 & \\
\hline
\end{tabular}


Independent sample $t$ - test was used to test above hypothesis and it was found that calculated value of $(t)$ is not significant at (0.05) which means that there are differences between Sameh Mall and Khalid Mall that are attributed to employees.

\section{H5: There are differences between Sameh Mall and Khalid Mall that are attributed to physical evidence.}

Table 9. Analysis of fifth hypothesis

\begin{tabular}{lllll}
\hline sample & $\mathrm{N}$ & Mean & Std. Deviation & $\mathrm{t}$ \\
\hline Sameh Mall & 163 & 5.0999 & 1.27481 & -1.413 \\
Khaled Market & 177 & 5.2663 & .83054 & \\
\hline
\end{tabular}

Independent sample $t$ - test was used to test above hypothesis and it was found that calculated value of $(t)$ is not significant at $(0.05)$ which means that there are no differences between Sameh Mall and Khalid Mall that are attributed to physical evidence.

\subsection{Reliability Test}

A Cronbach Alpha test was used to ascertain instrument reliability. The value was $=0.944$ for the questionnaire. All values are accepted since they are more than 0.60 (Malhotra, 2004, p. 268). Table 10 reveals Cronbachs' Alpha test for each item in the questionnaire.

Table 10. Reliability analysis of the study scales

\begin{tabular}{ll}
\hline Variables & Cronbach's alpha value \\
\hline Product quality & 0.843 \\
Product Range & 0.824 \\
prices & 0.854 \\
employees & 0.848 \\
Physical evidence & 0.884 \\
\hline
\end{tabular}

The result showed alpha for each variable is greater than accepted percent 0.60 , which is a reasonable value indicating the tool consistency that enhanced its use for the study.

\section{Discussion}

According to the analysis of the questionnaires, it can be found that there appeared no differences between the two case studies that are attributed to the five variables except for the prices. In that sense, it can be easily put into perspective that nature of the culture within the province which was chosen by the author. The author has chosen to apply the study in Zarqa, which is one of the Jordanian provinces. The nature of the Jordanian families in Zarqa are known to be of the middle class who are either self-employed or governmental employees and as it can be seen from the analysis that the sample which responded to the questionnaire was individuals who were either working in the private/public sector or self employed, meaning that the individuals were with limited income and it is natural for a family with a limited income to take a good care of the place's prices and level of items prices that they get. They tend to avoid overpriced items and get the items that are well-known and available every time they need them. From the perspective of Li and others (2012) it can be seen that the prices issue is not a type of customer loyalty. Also Yoo \& Park (1998) who applied their study in Korea found out that people were not that sensitive to the issue of the prices and it appeared that prices are not that influential as long as the service and the atmosphere are suitable for the customers. On the other hand, the results of the study found matched the results of a study by Terblanche \& Boshoff (2004) who found out the existence of a strong relationship between the customer loyalty to a certain store and the prices that this store offers. Torlak and others (2010) found in their study that the prices are among the attraction factors that attract people to a certain store which raises the level of satisfaction and loyalty.

Based on the analysis of the study, the author recommends the following:

- Khalid mall should run a market study on the recent prices of the items and the approach to run the most influential promotions that may attract more customers.

- The physical evidences of the store are not that important when it comes to decorations; it is more important when it comes to the comfort and the space and the accessibility to move from a place to another. 
- $\quad$ The variety and diversity of the items are among the influential factors that may attract people and increase their loyalty to a certain store. So both malls have to take extra attention to the issues of having more than one brand of the same item.

- Employee's social manners are also one of the important factors that influence the customer loyalty to a certain store. Employees must be trained to deal with the needs of the customers in a better way in both Sameh and Khalid mall.

\section{Acknowledgement}

The author is grateful to the Applied Science Private University, Amman, Jordan, for full financial support granted to this research project (grant No. DRGS-2015-2016-43).

\section{References}

Aghaei, M., Asadollahi, A., Hassani, A., Chaboksavar, M., \& Chaleshi, C. (2013). Evaluating Internal and External Factors of Chain Store for Improvement in Iran: A Case Study (Etka Chain Stores). Research Journal of Applied Sciences, Engineering and Technology, 6(15), 2830-2838.

Clottey, T., Collier, D., \& Stodnick, M. (2008). Drivers of Customer Loyalty In A Retail Store Environment. Journal of Service Science, 1(1).

Fox, E. J., Montgomery, A. L., \& Lodish, L. M. (2004). Consumer Shopping and Spending Across Retail Formats. The Journal of Business, 77(2), s25-s60. https://doi.org/10.1086/381518

Hosseini, Z., \& Jayashree, S. (2014). Influence of the Store Ambiance on Customers' Behavior-Apparel Stores in Malaysia. International Journal of Business and Management, 9(10). https://doi.org/10.5539/ijbm.v9n10p62

Hussain, R., \& Ali, M. (2015). Effect of Store Atmosphere on Consumer Purchase Intention. International Journal of Marketing Studies, 7(2). https://doi.org/10.5539/ijms.v7n2p35

aura, V., Durga, P. C., \& Sharma, S. (2015). Service quality, service convenience, price and fairness, customer loyalty, and the mediating role of customer loyalty. International Journal of Bank Marketing, 33(4), 404-422. https://doi.org/10.1108/IJBM-04-2014-0048

Kearney, T., Coughlan, J., \& Kennedy, A. (2012). An Exploration of the Effects of the Servicescape on Customer and Employee Responses in a Grocery Retail Context. School of Accounting and Finance.

Kumar, A. (2010). The Effect of Store Environment on Consumer Evaluations And Behavior Toward Single-Brand Apparel Retailers. University of Tennessee, Knoxville.

Martinell, E., \& Balboni, B. (2012). Retail service quality as a key activator of grocery store loyalty. The Service Industries Journal, 32(14), 2233-2247. https://doi.org/10.1080/02642069.2011.582499

Mittal, K., \& Prashar, A. (2010). A Study of Diversity in Retail Purchase Behaviour in Food and Grocery in Punjab: An Aid to Formulate Retail Strategy. Vision: The Journal of Business Perspective, 14(4), $255-265$. https://doi.org/10.1177/097226291001400402

Moye, L. (2011). Influence of Shopping Orientations, Selected Environmental Dimensions with Apparel Shopping Scenarios, and Attitude on Store Patronage for Female Consumers. PhD. Virginia Polytechnic Institute and State University.

Pugazhenthi, P. (2004). Factors Influencing Customer Loyalty and Choice of Retailer While Buying Fast Moving Consumer Goods. Master's Thesis in Business Administration.

Rai, A., \& Medha, S. (2013). The Antecedents of Customer Loyalty: An Empirical Investigation in Life Insurance Context. Journal of Competitiveness, 5(2), 139-163. https://doi.org/10.7441/joc.2013.02.10

Rajic, T., \& Dado, J. (2013). Modeling the relationships among retail atmospherics, service quality, satisfaction, and customer behavioral intentions in an emerging economy context. Total Quality Management, 24(9), 1096-1110. https://doi.org/10.1080/14783363.2013.776759

Simon, D., Gomez, M., McLaughlinc, E., \& Wittink, D. (2009). Employee Attitudes, Customer loyalty, and Sales Performance: Assessing the Linkages in US Grocery Stores. Managerial and Decision Economics, 3(0), 27-41. https://doi.org/10.1002/mde.1433

Terblanche, N., \& Boshoff, C. (2004). The in-store shopping experience: A comparative study of supermarket and clothing store customers. S.Afr.J.Bus.Manage, 35(4). 
Thusyanthy, V., \& Senthilnathan, S. (2011). Customer Satisfaction in Terms of Physical Evidence and Employee Interaction. IUP Journal of Marketing Management, 11(3). https://doi.org/10.2139/ssrn.1939601

Torlak, Ö., Uzkurt, C., \& Özmen, M. (2010). Dimensions of service quality in grocery retailing: a case from Turkey. Management Research Review, 33(5), 413-422. https://doi.org/10.1108/01409171011041866

Zameer, A., \& Mukherjee, D. (2010). Food and Grocery Retail: Patronage Behavior of Indian Urban Consumers. South Asian Journal of Management, 18(1).

\section{Appendix A. Questionnaire}

\section{Dear participants:}

The aim of the current questionnaire is to gather the needed data about the general environment and the quality of the items within grocery stores from the perspective of customers, and examine of the degree of your satisfaction about the services and the items presented in this store. Please answer the following questionnaire and bear in mind that any information given in this document will be used for research purposes only.

Thank you.

\section{Researcher}

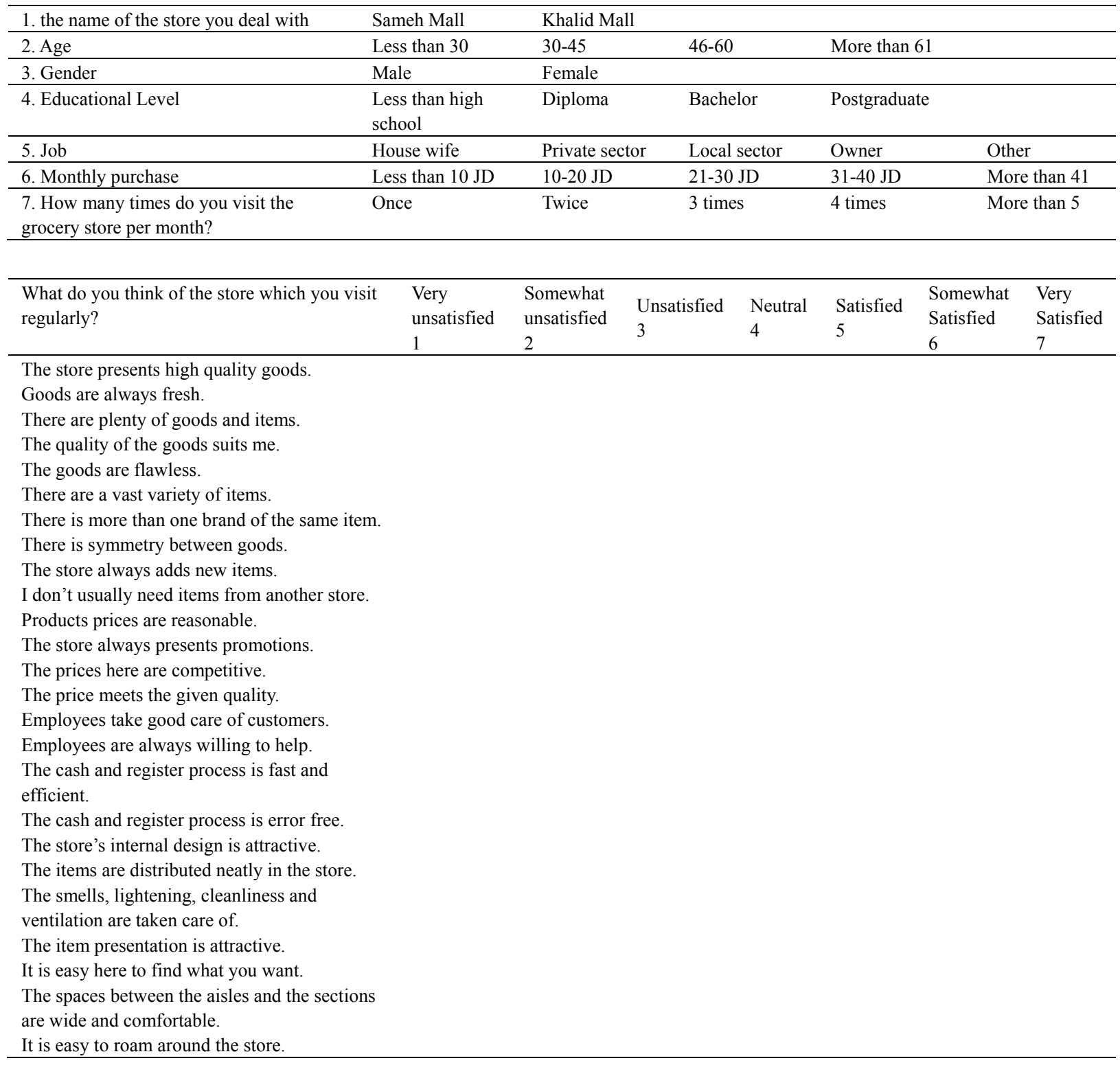




\section{Copyrights}

Copyright for this article is retained by the author, with first publication rights granted to the journal.

This is an open-access article distributed under the terms and conditions of the Creative Commons Attribution license (http://creativecommons.org/licenses/by/4.0/). 